\title{
Effect of Sand Ration on the Elastic Modulus of Self-Compacting Concrete
}

J. K. Su

Ph.D. Candidate, Institute of Materials Engineering, National Taiwan Ocean University, Keelung, Taiwan, R.O.C.

S. W. Cho

Ph.D. Candidate, Institute of Materials Engineering, National Taiwan Ocean University, Keelung, Taiwan, R.O.C.

C. C. Yang

Professor, Institute of Materials Engineering, National Taiwan Ocean University, Keelung, Taiwan, R.O.C.

R. Huang

Professor, Department of Harbor and River Engineering, National Taiwan Ocean University, Keelung, Taiwan, R.O.C.

Follow this and additional works at: https://jmstt.ntou.edu.tw/journal

Part of the Engineering Commons

\section{Recommended Citation}

Su, J. K.; Cho, S. W.; Yang, C. C.; and Huang, R. (2002) "Effect of Sand Ration on the Elastic Modulus of Self-

Compacting Concrete," Journal of Marine Science and Technology: Vol. 10: Iss. 1, Article 2.

DOI: $10.51400 / 2709-6998.2295$

Available at: https://jmstt.ntou.edu.tw/journal/vol10/iss1/2

This Research Article is brought to you for free and open access by Journal of Marine Science and Technology. It has been accepted for inclusion in Journal of Marine Science and Technology by an authorized editor of Journal of Marine Science and Technology. 


\section{Effect of Sand Ration on the Elastic Modulus of Self-Compacting Concrete}

Acknowledgements

The financial support of National Science Council in ROC under the grants NSC 89-2211-E-019-019 is gratefully appreciated. 


\title{
EFFECT OF SAND RATIO ON THE ELASTIC MODULUS OF SELF-COMPACTING CONCRETE
}

\author{
J. K. Su*, S. W. Cho*, C. C. Yang**, and R. Huang***
}

Key words: SCC, Flowability, Elastic modulus, S/A.

\begin{abstract}
In order to study the effect of sand ratio (S/A ratio, fine aggregate volume/total aggregate volume) on the elastic modulus of self-compacting concrete (SCC), concretes with various S/A ratios were cast and tested. Elastic moduli of SCC were compared with those of normal concrete. Slump flow test, slump test, and box test were carried out to evaluate concrete flowability. The flowability of SCC increases with an increase in S/A ratio. However, the elastic modulus of SCC is not significantly affected by S/A ratio when total aggregate volume is kept constant.
\end{abstract}

\section{INTRODUCTION}

Self-compacting concrete was developed in Japan in the early 1990s. Okamura [1] pointed out that SCC can flow into any corner and pass through the spacing of reinforcement without vibrating. The major advantages of SCC over conventional concrete are: high mobility, high resistance to segregation and no need of vibration. Okamura and Ozawa [2] also pointed out that in SCC mixes not only the coarse aggregate content might be limited but also the pozzolans and superplasticizer might be used to prevent segregation and increase flowability. Yurugi et al. [3] reported that the coarse aggregate content has significant effect on the filling capacity of concrete. The coarse aggregate volume of SCC was suggested to be about $50 \%$ of the solid volume (about 0.28 to $0.33 \mathrm{~m}^{3} / \mathrm{m}^{3}$ ) by Okamura [1], which was lower than that for normal concrete mixes $\left(>0.35 \mathrm{~m}^{3} / \mathrm{m}^{3}\right)$.

Hirsch [4] pointed out that elastic modulus of cement paste is influenced by the water/cement ratio and age. The empirical elastic moduli of concretes with

Paper Received March 15, 2001. Author for Correspondence: C. C. Yang. *Ph.D. Candidate, Institute of Materials Engineering, National Taiwan Ocean University, Keelung, Taiwan, R.O.C.

**Professor, Institute of Materials Engineering, National Taiwan Ocean University, Keelung, Taiwan, R.O.C.

***Professor, Department of Harbor and River Engineering, National Taiwan Ocean University, Keelung, Taiwan, R.O.C. different aggregates were also discussed and an equation for estimating concrete elastic modulus was derived. Based on the individual elastic modulus and volume fraction of the components, Hashin and Shtrikman [5] proposed the variational principle to obtain bounds of elastic moduli of composite materials. Mori and Tanaka [6] applied the average concept to analyze macroscopic properties of composite materials. In addition, the shape effect of inclusions was introduced in Eshelby's [7] method to asses the properties of composite materials. Yang and Huang proposed the single inclusion model [8] and double inclusion model [9] for approximating elastic modulus of concrete by employing both MoriTanaka theory and Eshelby's method.

For achieving the flowability requirements of SCC, slump test, slump flow test, and box test were carried out in this study. The elastic moduli of cement paste and concrete were obtained to evaluate the influence of S/A ratio on the elastic modulus of concrete.

\section{EXPERIMENTAL PROGRAM}

In this study, concrete was considered as a composite material in which fine aggregate and coarse aggregate were embedded in a matrix of cement paste. In order to study the effect of S/A ratio on the elastic modulus and flowability of cement-based material, various $\mathrm{S} / \mathrm{A}$ ratios were considered in the concrete mixes.

\section{Cement Paste (Matrix)}

Cement paste specimens were made of ASTM Type I Portland cement (specific gravity: 3.15), slag (specific gravity: 2.2), fly ash (specific gravity: 1.66), and water. Superplasticizer was adjusted to keep required slump and slump flow. The surface of the specimens was smoothed and covered by wet burlap. After demolding, the cylindrical specimens $(\phi 100 \times$ $200 \mathrm{~mm})$ were cured in water $\left(23^{\circ} \mathrm{C}\right)$ until the time of testing. The elastic moduli of the specimens were measured according to ASTM Test Method for Static Modulus of Elasticity and Poisson's Ratio of Concrete 
Table 1. Mix proportions of concrete

\begin{tabular}{ccccccccc}
\hline $\begin{array}{c}\text { Mix } \\
\text { No. }\end{array}$ & $\begin{array}{c}\text { Water } \\
\left(\mathrm{kg} / \mathrm{m}^{3}\right)\end{array}$ & $\begin{array}{c}\text { Sp } \\
\left(\mathrm{kg} / \mathrm{m}^{3}\right)\end{array}$ & $\begin{array}{c}\text { Cement } \\
\left(\mathrm{kg} / \mathrm{m}^{3}\right)\end{array}$ & $\begin{array}{c}\text { Fly Ash } \\
\left(\mathrm{kg} / \mathrm{m}^{3}\right)\end{array}$ & $\begin{array}{c}\text { Slag } \\
\left(\mathrm{kg} / \mathrm{m}^{3}\right)\end{array}$ & $\begin{array}{c}\text { Fine Aggregate } \\
\left(\mathrm{kg} / \mathrm{m}^{3}\right)\end{array}$ & $\begin{array}{c}\text { Coarse Aggregate } \\
\left(\mathrm{kg} / \mathrm{m}^{3}\right)\end{array}$ & $\begin{array}{c}\text { S/A } \\
(\%)\end{array}$ \\
\hline P & 482 & 15.0 & 746 & 149 & 348 & 0 & 0 & - \\
$\mathrm{A}$ & 185 & 6.2 & 286 & 57 & 133 & 481 & 1110 & 30.0 \\
$\mathrm{~B}$ & 185 & 5.9 & 286 & 57 & 133 & 641 & 951 & 40.0 \\
$\mathrm{C}$ & 185 & 6.5 & 286 & 57 & 133 & 722 & 872 & 45.0 \\
$\mathrm{D}$ & 185 & 5.7 & 286 & 57 & 133 & 762 & 832 & 47.5 \\
$\mathrm{E}$ & 185 & 6.3 & 286 & 57 & 133 & 802 & 793 & 50.0 \\
$\mathrm{~F}$ & 185 & 5.8 & 286 & 57 & 133 & 842 & 753 & 52.5 \\
$\mathrm{G}$ & 185 & 7.0 & 286 & 57 & 133 & 882 & 713 & 55.0 \\
\hline
\end{tabular}

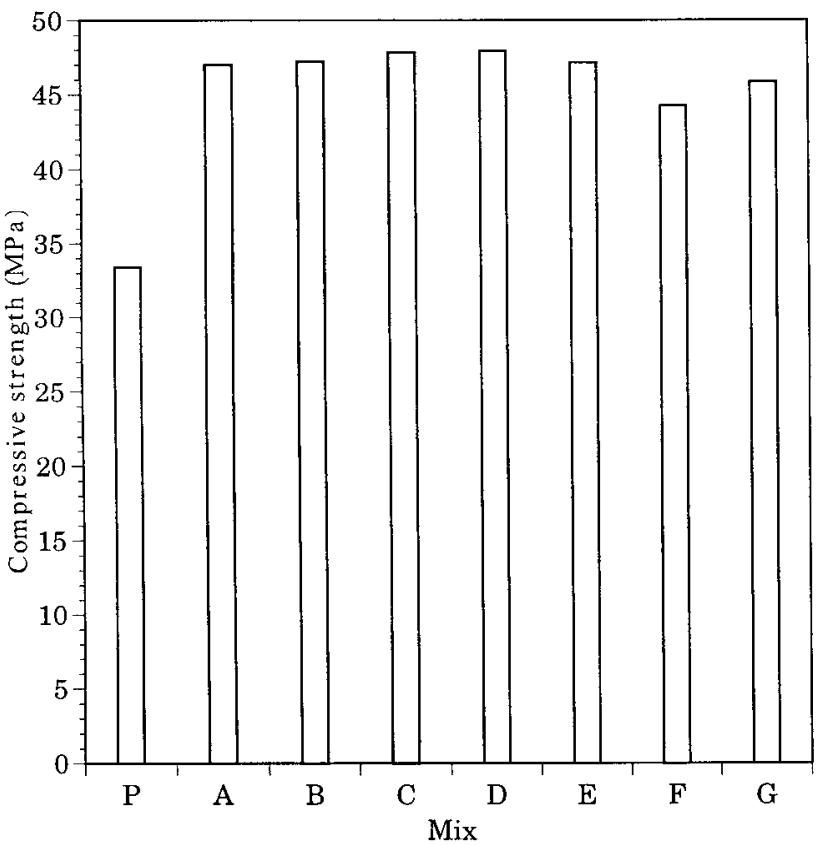

Fig. 1. Compressive strength of concrete.

in Compression (C469-94) [10].

\section{Concrete (Composite)}

Concrete specimens were made of ASTM Type I Portland cement, slag, fly ash, superplasticizer, water, fine aggregate, and coarse aggregate. Natural sand (specific gravity: 2.63) was used as fine aggregate and crushed limestone (specific gravity: 2.60) with a maximum size of $10 \mathrm{~mm}$ was used as coarse aggregate. Six different $\mathrm{S} / \mathrm{A}$ ratios $(\mathrm{S} / \mathrm{A}=0.3,0.4,0.45,0.475,0.5,0$. 525 , and 0.55 ) were considered in the mix proportions. The aggregate volume fraction was 0.6 for all mixes. The concrete mix design is given in Table 1. The water/ binder ratio was 0.4 . Concrete cylinders $(\phi 100 \times 200$ $\mathrm{mm}$ ) were cast and cured. The elastic moduli and compressive strengths of the specimens were measured according to ASTM C469-94 [10] and ASTM C39-81 [11]. The compressive strength used as a property index is presented in Fig. 1.

\section{Measurements and Procedures}

Slump flow test, slump test, and box test were carried out to evaluate concrete flowability. The workability of concrete was indicated by the slump of the material measured in a slump test according to ASTM C143. Slump flow test was used to determine the ability of the concrete to deform in non-restricted condition. A normal slump cone was used and the mold was filled with concrete. The mold was then lifted away vertically and the final diameter was measured. Once the concrete had stopped flowing, it had to be checked to determine any separation effects. No bleeding should occur and the larger aggregates had to be distributed evenly. In the box test as shown in Fig. 2, fresh concrete was poured in chamber $\mathrm{A}$ and then after the partition was lifted up it passed through the rebar spacing into chamber $B$. The rheological properties were measured by the filling height $(\mathrm{hb})$ in chamber B. Experimental results of slump, slump flow, and filling height are tabulated in Table 2.

\section{RESULTS AND DISCUSSION}

\section{Fresh Concrete}

To examine passability of concrete, box test was carried out. According to the suggestion of Japan Society of Civil Engineering (JSCE) [12], the filling height of concrete exceeding $300 \mathrm{~mm}$ is recommended as SCC. The slump and filling height $\left(\mathrm{h}_{\mathrm{b}}\right)$ of all mixes with various S/A ratios are shown in Fig. 3. Except for Mix A, the slumps (between $25 \mathrm{~cm}$ and $26.5 \mathrm{~cm}$ ) are 
Table 2. Test results of fresh concrete

\begin{tabular}{ccccccc}
\hline $\begin{array}{c}\text { Mix } \\
\text { No. }\end{array}$ & $\begin{array}{c}\text { S/A } \\
(\%)\end{array}$ & $\begin{array}{c}\text { Coarse Aggregate } \\
\text { Volume }\left(\mathrm{m}^{3} / \mathrm{m}^{3}\right)\end{array}$ & $\begin{array}{c}\text { Fine Aggregate } \\
\text { Volume }\left(\mathrm{m}^{3} / \mathrm{m}^{3}\right)\end{array}$ & $\begin{array}{c}\text { Slump } \\
(\mathrm{mm})\end{array}$ & $\begin{array}{c}\text { Slump Flow } \\
(\mathrm{mm})\end{array}$ & $\begin{array}{c}\text { Filling Height } \\
\mathrm{h}_{\mathrm{b}}(\mathrm{mm})\end{array}$ \\
\hline A & 30.0 & 0.42 & 0.18 & 195 & 350 & 25 \\
B & 40.0 & 0.36 & 0.24 & 250 & 510 & 200 \\
C & 45.0 & 0.33 & 0.27 & 255 & 540 & 255 \\
D & 47.5 & 0.32 & 0.28 & 260 & 550 & 320 \\
E & 50.0 & 0.30 & 0.30 & 260 & 570 & 340 \\
F & 52.5 & 0.28 & 0.32 & 265 & 610 & 340 \\
G & 55.0 & 0.27 & 0.33 & 265 & 650 & 340 \\
\hline
\end{tabular}

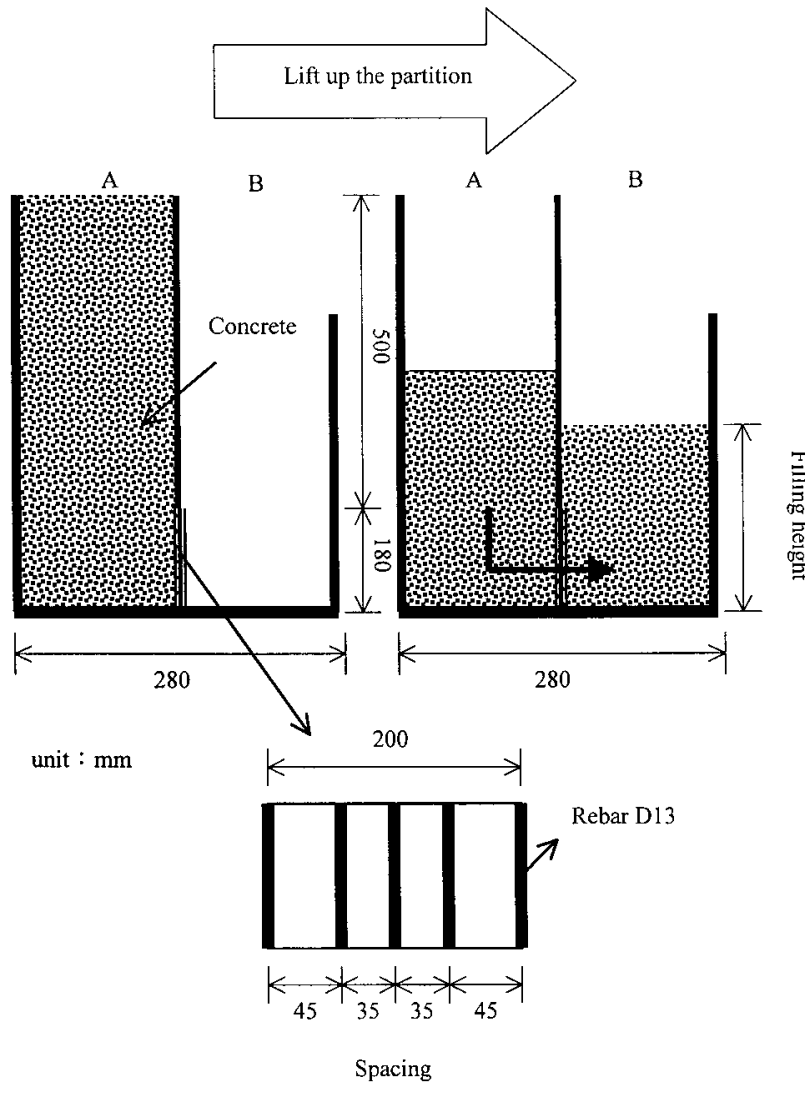

Fig. 2. Schematic diagram of box test.

almost the same for the concrete mixes. But the filling height increases with an increase in the S/A ratio. In order to describe the flowability of SCC, not only the slump test but also the box test are performed. The filling height of box test and slump flow vs. S/A curves are shown in Fig. 4. It appears when S/A is higher than 0.475 , the concrete can pass the box test. And the filling height and slump flow increase with an increase in the S/A ratio. Particle packing characteristics may play a significant role on the concrete flowability. According to the test results in Fig. 4 and the suggestion of Japan

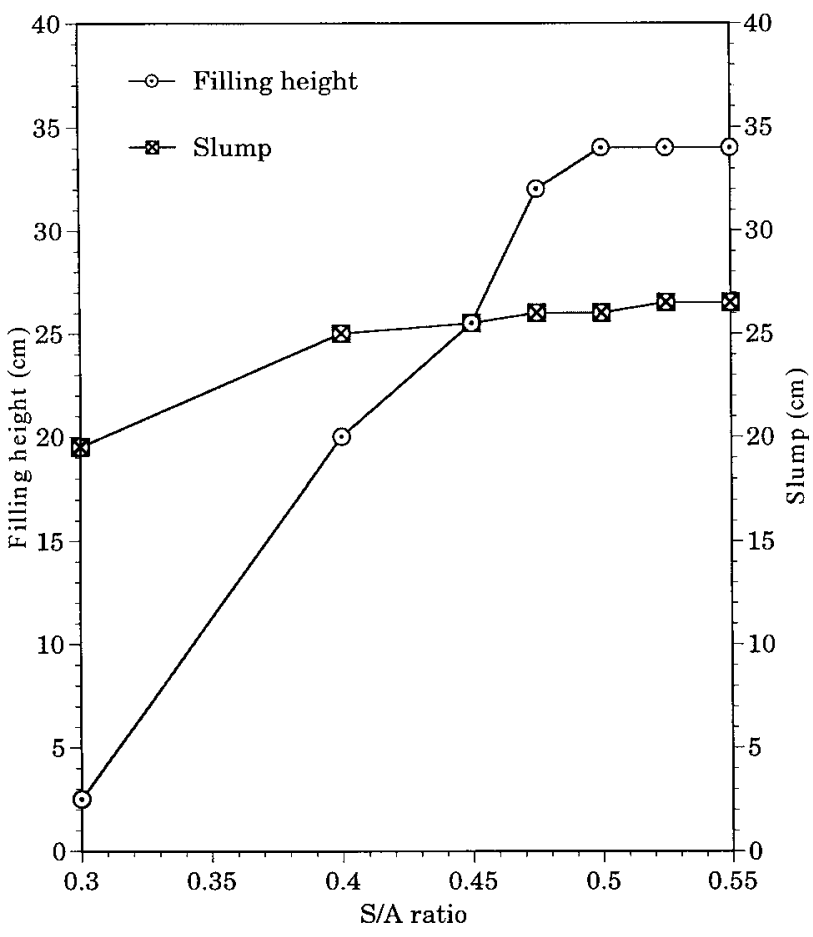

Fig. 3. Filling height and slump vs. S/A ratio.

Society of Civil Engineering (JSCE) [12], the S/A ratio for SCC is suggested to be 0.475 .

\section{Hardened Concrete}

The mineralogical composition of aggregate affects its elastic modulus, which in turn influence the elastic modulus of harden concrete. Many researchers (Hirch [4], Mehta and Monteiro [13]) have investigated the elastic modulus of aggregate. The single-inclusion model based on Mori-Tanaka Theory and Eshelby's Method in which the stress disturbance due to inhomogeneities under the applied compressive stress. In the previous work, the overall average elastic modulus tensor of cement-based materials $\underset{\sim}{\overline{\mathbf{c}}}$ was given by [8] 
Table 3. Elastic moduli of cement paste, mortar, and fine aggregate (GPa)

\begin{tabular}{cccc}
\hline Designation & Cement Paste & Cement Based Materials & Aggregate \\
\hline S1 & 24.91 & 31.09 & 36.63 \\
S2 & 21.43 & 29.08 & 36.38 \\
S3 & 18.71 & 27.50 & 36.97 \\
\hline R1 & & Average $=36.73$ \\
R2 & 24.91 & 31.09 & 36.51 \\
R3 & 21.43 & 29.17 & 36.78 \\
\hline
\end{tabular}

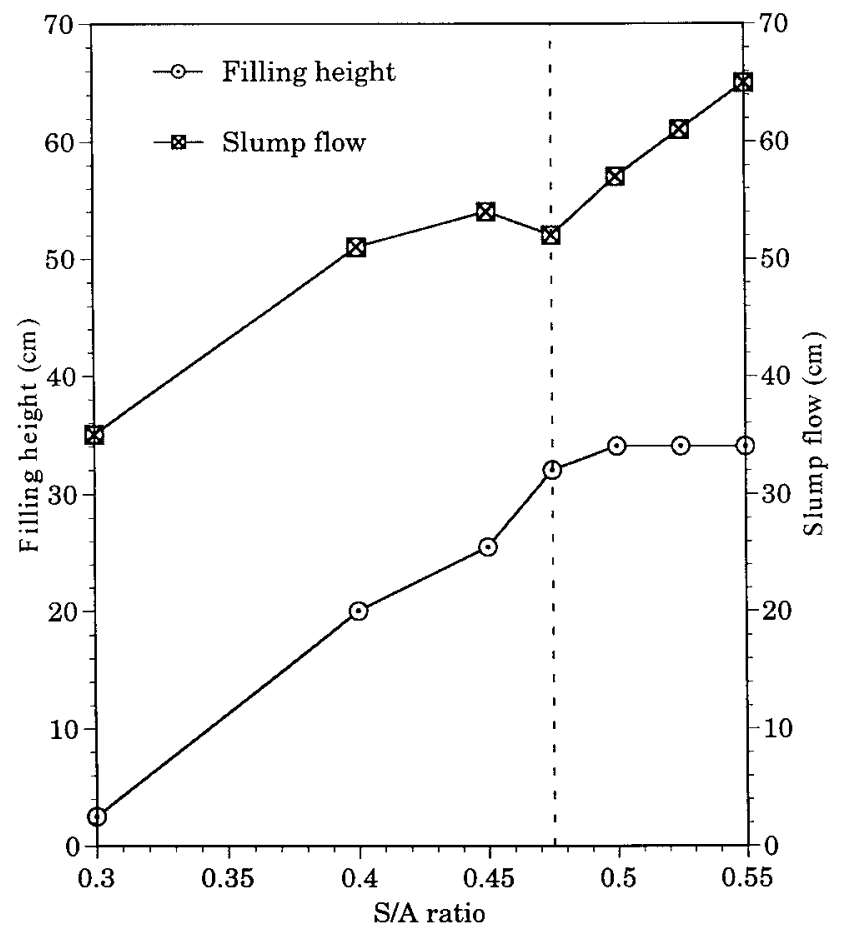

Fig. 4. Filling height and slump flow vs. S/A ratio.

$\overline{\mathcal{C}}=\left\{\mathcal{c}^{-1}+f\left[\left\{(1-f)\left(\mathcal{c}^{*}-\mathcal{c}\right) \underset{\mathcal{L}}{-}-f\left(c-\mathcal{c}^{*}\right)+\mathcal{c}\right\}^{-1}\right]^{-1}\left(\mathcal{c}-\mathcal{c}^{*}\right) \mathcal{c}^{-1}\right\}^{-1}$,

where $\underset{\sim}{c}$ and $\underset{\sim}{c^{*}}$ are the elastic modulus tensor of matrix and inclusion, respectively. $f$ is the volume fraction of inclusion. $\underset{\sim}{S}$ is the Eshelby's tensor (see Appendix).

In the previous work [8], two types of singleinclusion cement-based materials were used. One was cement past with river sand (fine aggregate) and the other was cement paste with crushed stone (coarse aggregate). The aggregate volume ratio (aggregate volume/concrete volume) of $58 \%$ was used. Three different water/cement ratios $(\mathrm{w} / \mathrm{c}=0.26,0.3$, and 0.34$)$ were selected. The elastic moduli of cement paste and cement-based materials were measured according to the specifications of ASTM C469-81 and presented in Table 3. Notation for the specimens is such that the first letter indicates two different aggregates $S$ and $R$, and the second number 1,2 , and 3 indicates three different w/c ratios $0.26,0.30$, and 0.34 , respectively. Equation (1) was used to calculate the elastic moduli of the fine aggregate and coarse aggregate using the single-inclusion model and experimental results.

The double-inclusion method is applied to calculate the equivalent elastic modulus of concrete. The inclusions are divided into two groups: fine aggregate and coarse aggregate. The overall elastic moduli of the concrete composite materials, $\bar{C}$, are given as

$$
\overline{\widetilde{C}}=\left(C^{-1}+f_{1} \alpha+f_{1} \beta\right)^{-1}
$$

where $\alpha$ and $\beta$ are the computed parameters [9], $f_{1}$ and $f_{2}$ are the volume ratio of fine aggregate and coarse aggregate, respectively.

In the theoretical approach, the elastic moduli of cement paste and aggregate were used as listed in Table 3. The volume ratios of fine aggregate and coarse aggregate were obtained from Table 1. The elastic modulus of SCC was calculated from eqn. (2). Figure 5 shows the relationship between concrete elastic modulus and S/A ratio. The experimental results are also illustrated in Fig. 5. Since the elastic moduli of fine aggregate and coarse aggregate are not much different and the total volume of aggregate is constant, the calculated and experimental concrete elastic moduli are almost the same. In this study, when the total volume of aggregate is kept constant, the concrete elastic moduli are not significantly influenced by the S/A ratios.

\section{Elastic Modulus and Filling Height}

The concrete elastic modulus and the filling height 


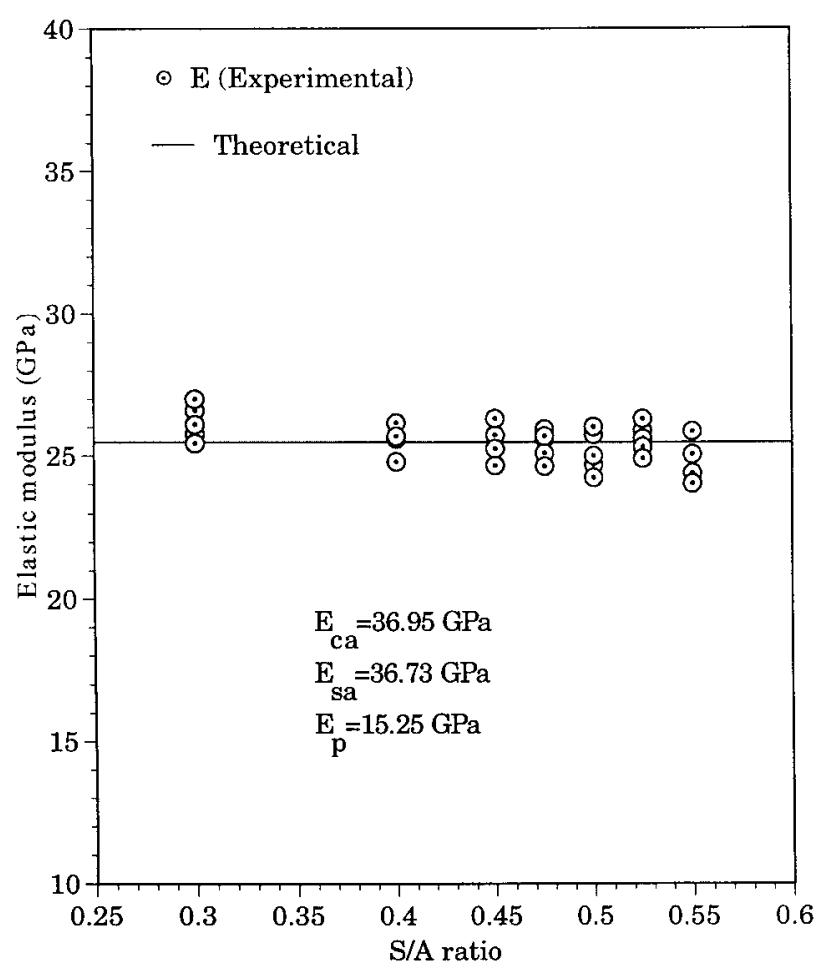

Fig. 5. Concrete elastic modulus vs. S/A ratio.

vs. S/A curves are shown in Fig. 6. The corresponding theoretical results are also illustrated in Fig. 6. The graph correlates the S/A ratio with the elastic modulus of the concrete for various elastic modulus ratios of fine aggregate and coarse aggregate $\left(E_{f a} E_{c a}\right.$, elastic modulus of fine aggregate/elastic modulus of coarse aggregate). It appears that the filling height of box test sharply increases form $2.5 \mathrm{~cm}$ to $32 \mathrm{~cm}$ as the S/A ratio increases from $30 \%$ to $47.5 \%$. From the experimental results, the elastic modulus of concrete is not significantly affected when the S/A ratio increases. When (elastic modulus of fine aggregate) is 2 times of (elastic modulus of coarse aggregate), the elastic modulus of concrete increases from 28.00 GPa to 29.66 Gpa when the S/A ratio increases from $30 \%$ to $47.5 \%$. When $E_{f a}$ is half of $E_{c a}$, the elastic modulus of concrete decreases from $22.54 \mathrm{Gpa}$ to $21.00 \mathrm{Gpa}$ when the S/A ratio increases from $30 \%$ to $47.5 \%$. It shows that elastic modulus of concrete is influenced by the elastic properties and the volume fraction of aggregate.

\section{CONCLUSIONS}

The S/A ratio is an important material parameter of SCC and the rheological properties increase with an increase in the S/A ratio. Within the scope of this study, the proper S/A ratio for SCC is suggested to be $47.5 \%$.

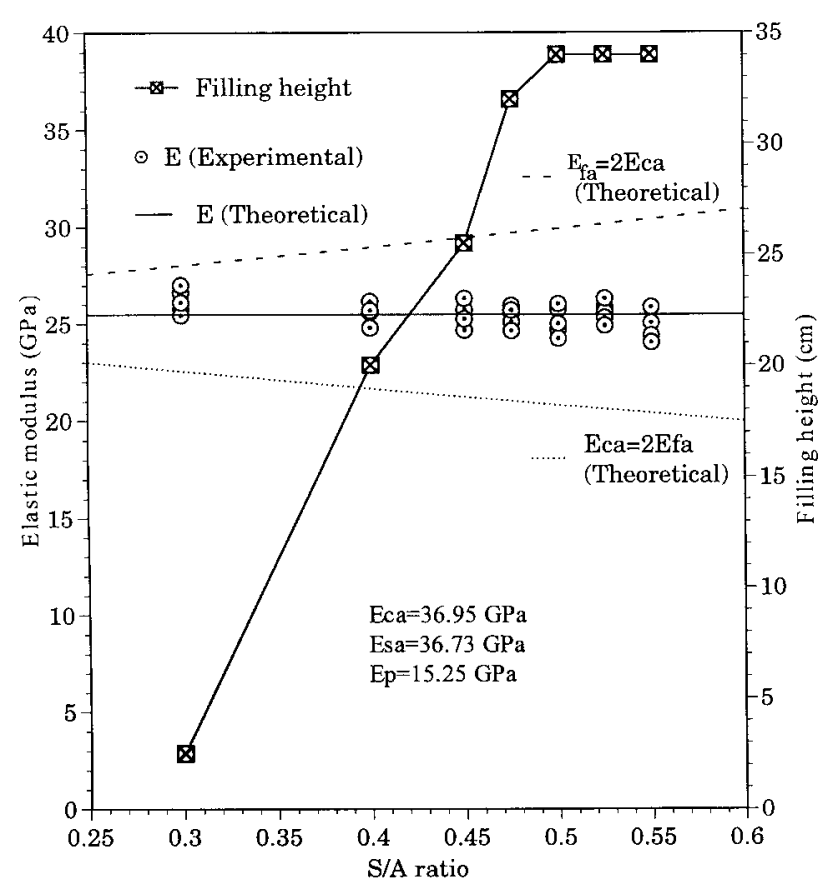

Fig. 6. Concrete elastic modulus and filling height vs. S/A ratio.

The elastic modulus of concrete is influenced mainly by the elastic properties of matrix, fine aggregate and coarse aggregate. However, when the elastic moduli of fine aggregate and coarse aggregate are not much different and the total volume of aggregate is constant, the elastic modulus of SCC is not significantly affected by S/A ratio.

\section{ACKNOWLEDGMENT}

The financial support of National Science Council in ROC under the grants NSC 89-2211-E-019-019 is gratefully appreciated.

\section{REFERENCE}

1. Okamura, H., "Self-Compacting High-Performance Concrete," Concrete International, Vol. 19, No. 7, pp. 50-54 (1998).

2. Okamura, H. and Ozawa, K., "Mix-design for SelfCompacting Concrete", Concrete library of JSCE, Vol. 25, pp. 107-120 (1995).

3. Yurugi, M., Sakata, N., Iwai, M. and Sakai, G., "Mix Proportion for Highly Workable Concrete," Proceedings, Concrete 2000, Dundee, pp. 579-589 (1989).

4. Hirsch, T.J., " Modulus of Elasticity of Concrete Affected by Elastic Moduli of Cement Paste Matrix and Aggregate," ACI Material Journal, pp. 427-451 (1962).

5. Hansen, Z. and Shtrikman, S., "On Some Variational 
Principles in Anisotropic and Nonhomogeneous Elasticity," J. Mech. Phys. Solids, Vol. 10, pp. 335-343 (1962).

6. Mori, T. and Tanaka, K., "Average Stress in Matrix and Average Energy of Materials with Misfitting Inclusions," Acta Metall., Vol. 21, pp. 571-574 (1973).

7. Eshelby, J.D., "The Determination of the Elastic Field of an Ellipsoidal Inclusion, and Related Problems," Proc. Roy. Soc., A241, pp. 376-396 (1957).

8. Yang, C.C., and Huang, R., "Effect of S/A Ratio on the Elastic Modulus of Cement-based Materials", Journal of the Chinese Institute of Engineers, Vol. 21, No. 3, pp. 357-364 (1998).

9. Yang, C.C. and Huang, R., "Double Inclusion Model for Approximate Elastic Moduli of Concrete Material," Cement and Concrete Research, Vol. 26, No. 1, pp.8391 (1996).

10. ASTM Test Method for Static Modulus of Elasticity and Poisson's Ratio of Concrete in Compression (C-469), American Society for Testing and Materials, Philadelphia.

11. ASTM Test Method for Compressive Strength of Cylindrical Concrete Specimen (C-39), American Society for Testing and Materials, Philadelphia.

12. Japan Society of Civil Engineering, Recommendations for Construction of Self-Compacting Concrete, JSCE (1998).

13. Mehta, P.K. and Monteiro, P.J.M., Concrete: Structure, Properties, and Materials, Second Edition, Prentice Hall, New Jersey, N. J., pp. 256-257 (1993).

14. Mura, T, Micromechanics of Defects in Solids, Second Revised Edition, Martinus Nijhoff Publishers, The Hague, The Netherlands, pp. 364-380 (1987).

\section{APPENDIX}

Eshelby's tensor $\underset{\sim}{S}$ for sphere inclusion is listed below [14]

$$
\begin{aligned}
& S_{111}=S_{222}=S_{333}=\frac{7-5 v}{15(1-v)} . \\
& S_{1122}=S_{2233}=S_{3311}=S_{2211}=S_{3322}=\frac{5 v-1}{15(1-v)} . \\
& S_{1212}=S_{2323}=S_{3131}=\frac{4-5 v}{15(1-v)} .
\end{aligned}
$$

\section{含砂率對流動化混凝土彈性模數之 影響}

穌錦江卓世偉楊仲家 國立台灣海洋大學材料工程研究所

$$
\text { 黄然 }
$$

國立台灣海洋大學河海工程系所

$$
\text { 摘 要 }
$$

本研究主要探討混凝土含砂率 (S/A，細骨材 體積/總骨材體積) 對流動化混凝土(SCC) 彈性模數 的影響。研究中以不同含砂率之混凝土配比進行彈性 模數試驗, 並與一般混凝土比較。混凝土流動性方面 則以坉度、坉流度、箱型試驗等進行評估。由試驗結 果得知, 流動化混凝土的流動性會隨著混凝土含砂率 增加而改善。然而對彈性模數而言, 當骨材總體積量 一定時, 改變混凝土含砂率對於彈性模數並沒有太大 的影響。 